\title{
ROS Accumulation and TTC Reduction in Growing Embryo of Crithmum maritimum L. Isolated from Water or Salt Imbibed Seeds
}

\author{
Abdallah ATIA, Chedly ABDELLY, Abderrazak SMAOUI \\ Laboratory of Extremophile Plants (LPE), Borj Cedria Centre of Biotechnology, Hammam-Lif, 2050, Tunisia; atbdllh@yahoo.fr
}

\begin{abstract}
The salinity induced inhibition of seeds germination remains not clear at physiological levels. The aims of this study is to investigate the effect of salt on germination, embryo growth, superoxide anion radical $\left(\mathrm{O}_{2}^{-}\right)$and the respiratory activity (TTC reduction) in Crithmum maritimum L. seeds. Thus the embryo growth, in situ localization of respiratory activity and superoxide anion radical $\left(\mathrm{O}_{2}^{-}\right)$localization, were investigated. Chlorure 2, 3, 5-triphényltétrazolium (TTC) reduction test and superoxide anion radical $\left(\mathrm{O}_{2}^{-}\right)$localization with Nitroblue Tetrazolium Chloride (NBT) were performed in embryo isolated from seeds of the halophyte Crithmum maritimum L either sown in distilled water or in $200 \mathrm{mM} \mathrm{NaCl}$. The key results show that germination was maximal (90\%) in distilled water, but was fully inhibited following seed exposure to $\mathrm{NaCl}$. The completion of the embryo growth (ca. $2 \mathrm{~mm}$ length) leading to the radicle emergence took $6 \mathrm{~d}$ in $\mathrm{H}_{2} \mathrm{O}$, but was markedly delayed by salt. $\mathrm{NaCl}$ reduced the elongation zone in the embryo axis, hence indicating that the cell division and/or cell elongation were disturbed by salinity. The respiratory activity (TTC reduction) and $\mathrm{O}_{2}$ production in the cotyledon were significantly lowered by salinity.
\end{abstract}

Keywords: embryo growth, germination, halophyte, salinity, superoxide anion radical, TTC reduction test

\section{Introduction}

The germination phase is preceded by the initiation of embryo elongation within the seeds (Nikolaeva, 1977; Baskin and Baskin, 2004), and subsequently the radicle elongation and protrusion through the surrounding tissues. These modifications constitute the germination sensu stricto (Bewly, 1997). This phase is relatively limited in time and is associated with the increase of the respiration activity, the initiation of cells division and the radicle elongation (Côme, 1982; Bewly, 1997; Homrichhausen et al., 2003; Mûller et al., 2009). These processes seem to be salt-sensitive, since salt-imbibed seeds show substantial delay in germination (Ashraf et al., 2002; Sebei et al., 2007; Voigt et al., 2009). In imbibed and germinating seeds, the reactivation of respiratory metabolism resulted in high levels of reactive oxygen species (ROS) accumulation (Garnczarska and Wojtyla, 2008). This was observed in germinating seeds of Raphanus sativus (Schopfer et al., 2001), Lupinus luteus (Garnczarska and Wojtyla, 2008) and Pisum sativum (Kranner et al., 2010). Although ROS are important components of stress response, they act as secondary messengers in signal transduction pathways that control processes in plant growth, development and germination (Schopfer et al., 2001; Bailly, 2004; Wojtyla et al., 2006; Kranner et al., 2010). There is evidence that the onset of germination metabolism is accompanied by intense production of ROS including hydrogen peroxide $\left(\mathrm{H}_{2} \mathrm{O}_{2}\right)$, the hydroxyl radical $(\cdot \mathrm{OH})$, the singlet oxygen $\left({ }^{1} \mathrm{O}_{2}\right)$ and the superoxide anion radical $\left(\mathrm{O}_{2}{ }^{--}\right)$(Bailly et al., 2008).

In plant cells, ROS generation and regulation are environmentally and physiologically regulated and depend on the growth stage (Passardi et al., 2005). In germinating seeds the ROS were shown to be implicated in radicle elongation. In Raphanus sativus, germination is accompanied by high peroxidase activity (Schopfer et al., 2001). In tomato, the peroxidase genes begin to expressed with the radicle elongation along with the onset of the reserve mobilization (Morohashi, 2002). This is also demonstrated in Brassica oleracea (Bellani et al., 2002). Peroxidases generates at the cell wall level the hydroxyl radicals, ${ }^{\circ} \mathrm{OH}$, from superoxide radical $\left(\mathrm{O}_{2}^{-}\right)$and hydrogen peroxide $\left(\mathrm{H}_{2} \mathrm{O}_{2}\right)$ (Schopfer et al., 2002). The ${ }^{\circ} \mathrm{OH}$ is highly reactive and capable of cleaving cell wall polysaccharides, such as pectin and xyloglucan (Fry, 1998). This may lead to radicle elongation and subsequently germination can occurs.

Crithmum maritimum L. (Apiaceae), a perennial halophyte, thriving along rocky coastal ecosystems, is potentially useful for economical and medicinal purposes (Meot-Duros et al., 2008; Meot-Duros and Magné, 2009; Atia et al., 2010a). The seeds of this species are characterized by an under-developed embryo, which achieves its growth within the seed before the germination starts. Salt response of several halophyte species is analogous to that of glycophytes at the germinative stage, showing maximal germination in salt-free media, and being strongly inhibit- 
ed by an increased salinity (Tobe et al., 2004; Debez et al., 2004; Joshi et al., 2005; Easton and Kleindorfer, 2008).

In previous investigations, we found that seed germination capacity of $C$. maritimum $\mathrm{L}$. was maximal in salt free media and that salinity inhibit germination, namely at higher levels (200 mM, NaCl) (Atia et al., 2006; MeotDuros and Magné, 2008). One may hypothesize that the salt-induced inhibition of germination in this halophyte could result from the restriction of the embryo growth or from the inhibition of some processes like respiratory metabolism in embryo. Therefore, the present study focuses on the impact of relatively high salinity $(200 \mathrm{mM} \mathrm{NaCl})$ on the embryo, and addresses the effects of salinity on respiration process and the production of the superoxide anion radical $\left(\mathrm{O}_{2}{ }^{-}\right)$in embryo tissues.

\section{Materials and methods}

Fruit harvesting, seed preparation and germination conditions

Mature fruits were collected in December 2007 from Tabarka (N-W of Tunisia, humid Mediterranean climate) and stored dry under laboratory conditions at $\left(18-23^{\circ} \mathrm{C}\right)$ until their utilization in January 2008. Seeds, from which the spongy coat was removed, were surface sterilized in a $3.5 \%$ calcium hypochlorite solution for $5 \mathrm{~min}$ before beginning the germination test. Twenty-five seeds were then placed in $9 \mathrm{~cm}$ Petri dish on a double layer of filter paper (type Filtrak), either moistened with distilled water or with a solution containing $100,200 \mathrm{mM}$, or $300 \mathrm{mM}$ $\mathrm{NaCl}$. For each treatment, 4 replicates (Petri dishes) were used. Petri dishes were sealed with transparent plastic film to prevent any evaporation. The germination test was carried out in a growth chamber at $18-23^{\circ} \mathrm{C}$ temperature regime and illuminated by five lamps (Type OS-RAM $40 \mathrm{~W}$, fluence of $25 \mu \mathrm{mol} \mathrm{m} \mathrm{m}^{-2} \mathrm{~s}^{-1}, 400-700 \mathrm{~nm}$ ) with $8 \mathrm{~h}$-dark/16 h-light regime.

\section{Microscopy and histochemical analysis}

For embryo growth, only seeds moistened with distilled water or with a solution containing $200 \mathrm{mM} \mathrm{NaCl}$ were used. For the embryo length, dry seeds or seeds imbibed for $3 \mathrm{~d}$ or $6 \mathrm{~d}$ were dissected under stereomicroscope and the embryos were isolated and fixed in a paraformalfdehyde solution $(2 \%)$ containing phosphate buffer $(\mathrm{pH}$ 7) and stored at $4^{\circ} \mathrm{C}$. The embryo length was determined under light microscope (type, Olympus DX41).

To study the embryo metabolic activities, a histochemical study of the respiratory activities with chlorure 2, 3 , 5-triphényltétrazolium (TTC) test and $\mathrm{O}_{2}^{--}$localization with Nitroblue Tetrazolium Chloride (NBT) test were performed on isolated embryo. The visualization of TTC reduction to red formazan was routinely used as viability test. The TTC is reduced by the mitochondrial dehydrogenases, particularly by the dehydrogenases of complex I. The efficiency of the red formazan formation depends on the activity of cytochrome oxidase (Block and Brouwer, 2002). Embryos were isolated from seeds imbibed either in distilled water or $200 \mathrm{mM} \mathrm{NaCl}$ solution, or from geminated seeds. TTC (Chlorure 2, 3, 5-triphényltétrazolium) test was performed. The dissected embryos were placed in $0.08 \%$ TTC solution for $20 \mathrm{~min}$ at $20^{\circ} \mathrm{C}$ under obscurity. The NBT (Nitroblue Tetrazolium Chloride) test was performed as described in Cordoba-Pedregosa et al. (2005). In brief, the embryos prepared as above-mentioned were placed in NBT solution for $20 \mathrm{~min}$ at $20^{\circ} \mathrm{C}$ under obscurity. In both tests, the reactions were stopped by placing the embryos in distilled water and the samples were gently washed with distilled water. The stained embryos, at least ten per treatment, were observed and photographed under stereomicroscope (Type Leica).

\section{Results}

\section{Seed germination capacity and Embryo growth following} imbibition in water or in $\mathrm{NaCl}$

The germination of seeds sown in distilled water started after $7 \mathrm{~d}$, reached about $85 \%$ after $12 \mathrm{~d}$ and was maximal (90\%) after 20 d. $100 \mathrm{mM}$ significantly reduced germination. Only some seeds germinated in $200 \mathrm{mM} \mathrm{NaCl}$ solution and $300 \mathrm{mM} \mathrm{NaCl}$ completely inhibited the germination over time (Fig. 1).

At full ripening seed (ca. $4 \mathrm{~mm}$ long), the embryo was about $1 \mathrm{~mm}$ long. After $3 \mathrm{~d}$ of seed imbibition in distilled water, the cotyledon and the embryo axis length increased from $0.58 \mathrm{~mm}$ and $0.62 \mathrm{~mm}$ respectively, to $0.8 \mathrm{~mm}$ for both tissues (Fig. 3A and 3B). For seeds imbibed in 200 $\mathrm{mM} \mathrm{NaCl}$, the growth of the cotyledon and the embryo axis were less important $(0.75 \mathrm{~mm}$ and $0.70 \mathrm{~mm}$, respectively). After $6 \mathrm{~d}$ of imbibition in distilled water, the cotyledon and the embryo axis length were $1.08 \mathrm{~mm}$ and 1.05 $\mathrm{mm}$ respectively, whereas it was only $0.85 \mathrm{~mm}$ for the cotyledon and $0.75 \mathrm{~mm}$ for the embryo axis in salt-imbibed seeds (Fig. 2A and 2B).

\section{Embryo metabolic activity: localization of respiratory} activity and $\mathrm{O}_{2}^{\circ}$ production

The embryos isolated from salt-imbibed seeds show a reduction of the respiratory activity in the cotyledons regions as compared to the cotyledons of embryos imbibed in distilled water. The germinating embryos showed a decrease in respiratory activity and in the elongation zone in embryo axis (Fig. 3). In general, the NBT staining test revealed that, independent of salt treatment, $\mathrm{O}_{2}{ }^{--}$was highly produced in embryos (Fig. 4 A, 4B and 4C). Salt treatment reduced the $\mathrm{O}_{2}^{--}$production in the cotyledon area, as compared to distilled water imbibed embryos and germinating embryos (Fig. 4 A, 4B and 4C). Lower $\mathrm{O}_{2}^{--}$production was also found in the elongation zones in the axis of embryos isolated from seeds imbibed in distilled water and in the germinating embryos (Fig. $4 \mathrm{~B}$ and $4 \mathrm{C}$ ). 
100

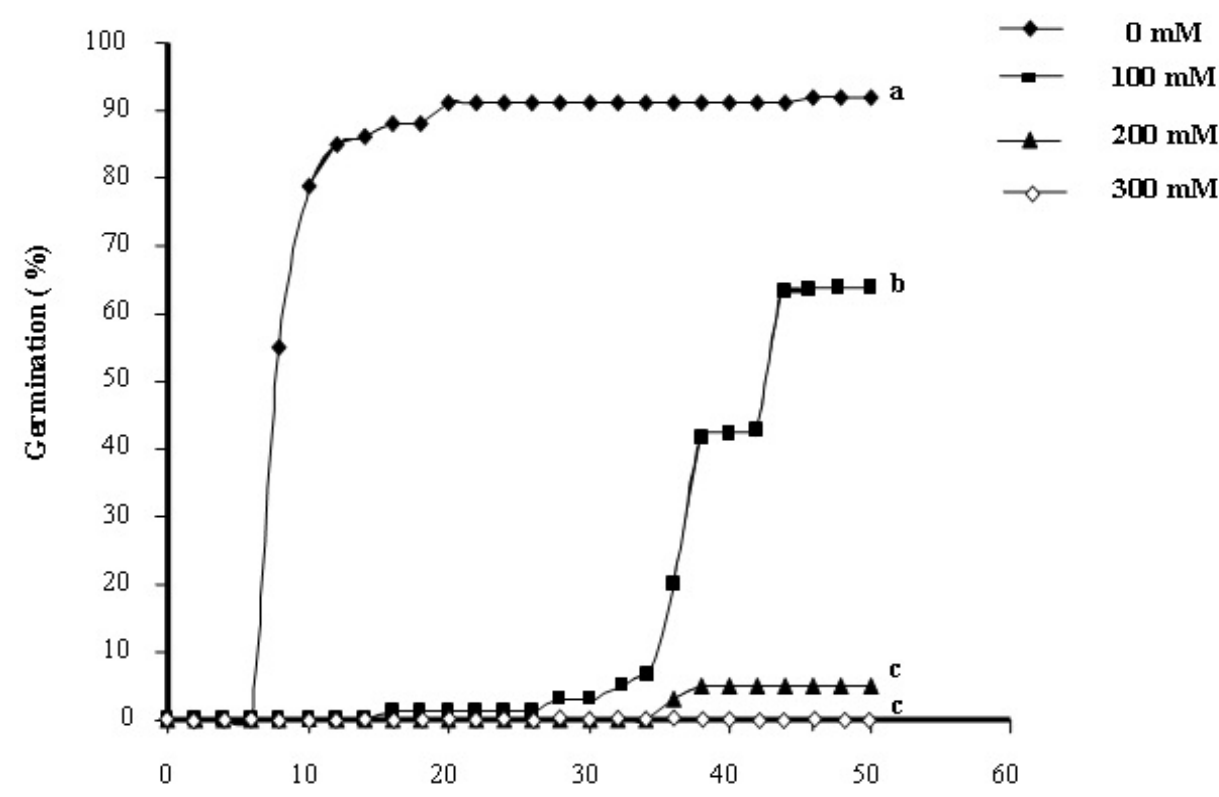

Fig. 1. C. maritimum L. seed germination (\%) over time in distilled water or $\mathrm{NaCl}$ (means \pm SE.)
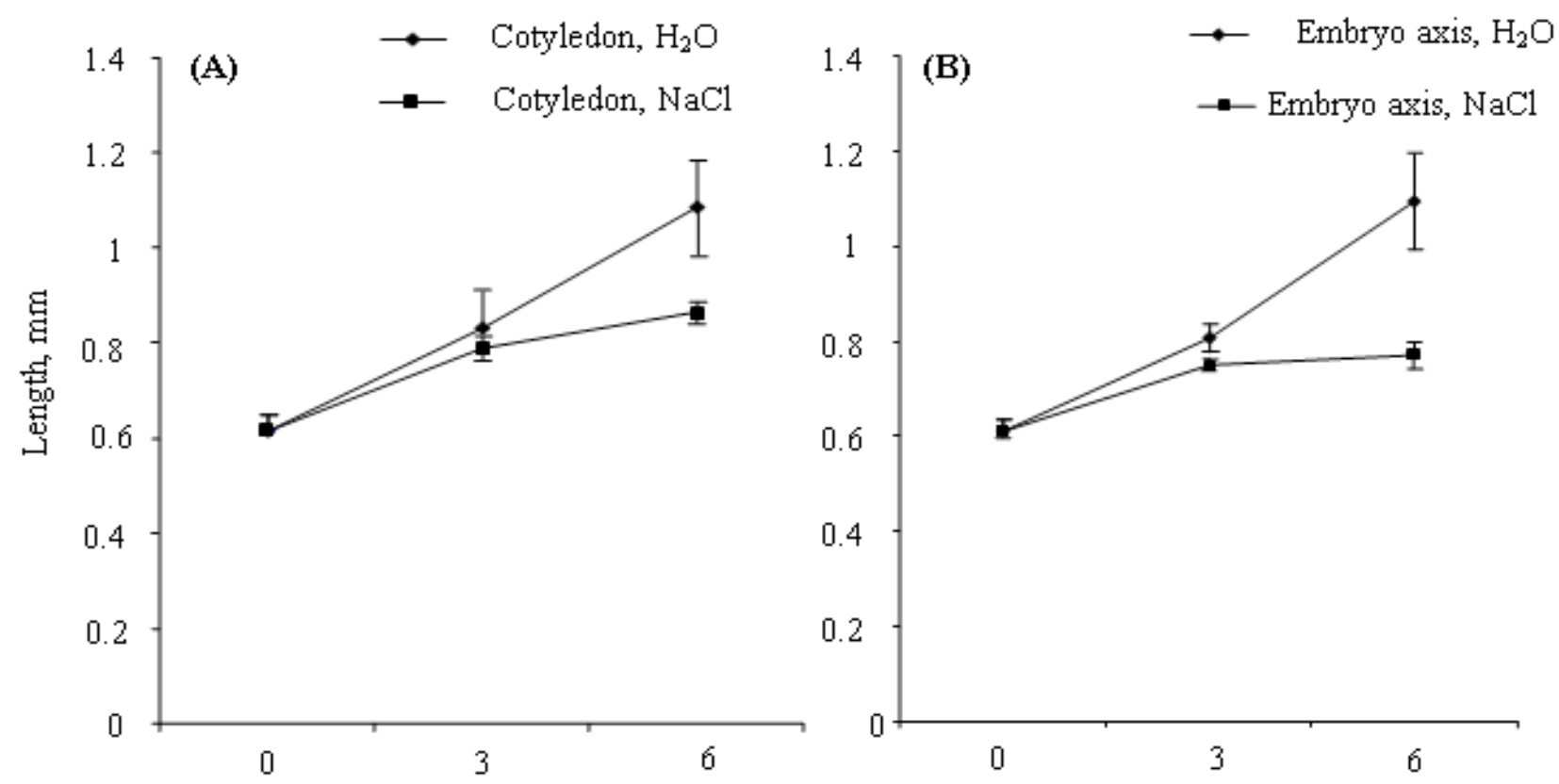

Time, $\mathrm{d}$.

Fig. 2. C. maritimum L. embryo growth within the seeds, during imbibition in distilled water or $200 \mathrm{mM} \mathrm{NaCl}$. (A) Cotyledon growth over time; (B) Axis growth over time; (means \pm SE)

\section{Discussion}

In distilled water the germination percentage of $C$. maritimum L. reached $90 \%$ after 22 d. Yet, salinity reduced or inhibited germination. In fact, $100 \mathrm{mM}$ significantly reduced germination, only some seeds could germinate in $200 \mathrm{mM} \mathrm{NaCl}$ and $300 \mathrm{mM} \mathrm{NaCl}$ completely inhibited the germination over time (Fig. 2). These results confirm previous studies either on this species (Atia et al., 2006) or on other halophytes (Debez et al., 2004; Joshi et al., 2005; Easton and Kleindorfer, 2008). How salinity inhibits the germination in halophytes is still controversial, but it is known that salt impacts this process, essentially through its osmotic and/or ionic components (Sosa et al., 2005; Tobe et al., 2004; Atia et al., 2010b).

Several species present morphologically dormant seeds. In this case, the embryo must elongate and reach a critical length before the radicle protrusion (Nikolaeva, 1977). In C. maritimum L. seeds, the embryo is underdeveloped 
A

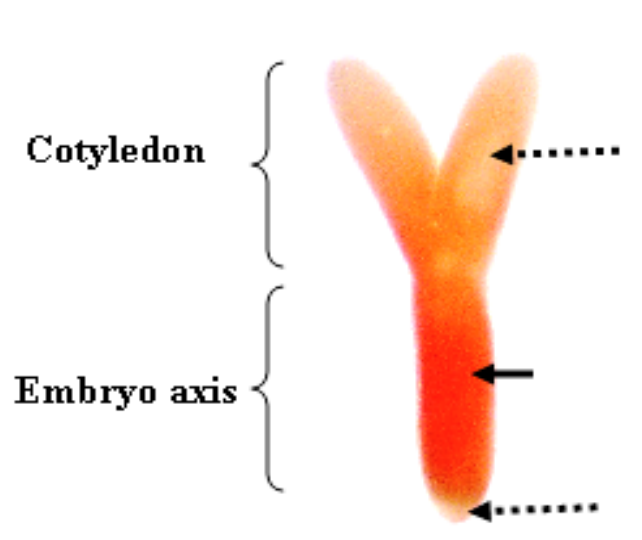

$0.5 \mathrm{~mm}$
B

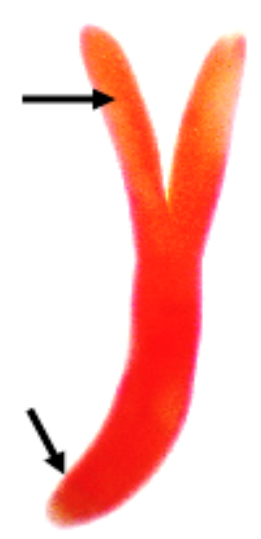

$0.5 \mathrm{~mm}$
$\mathrm{C}$

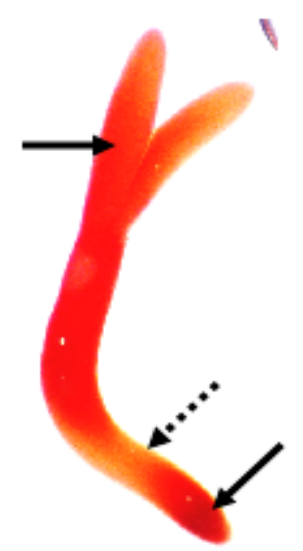

$0.5 \mathrm{~mm}$

Fig. 3. Histochemical localization of the TTC reduction in: (A) embryo isolated from salt imbibed seeds (B) water imbibed seeds (C) germinated embryo. The continuous arrows indicate high respiratory activity and the discontinuous arrows indicate low respiratory activity

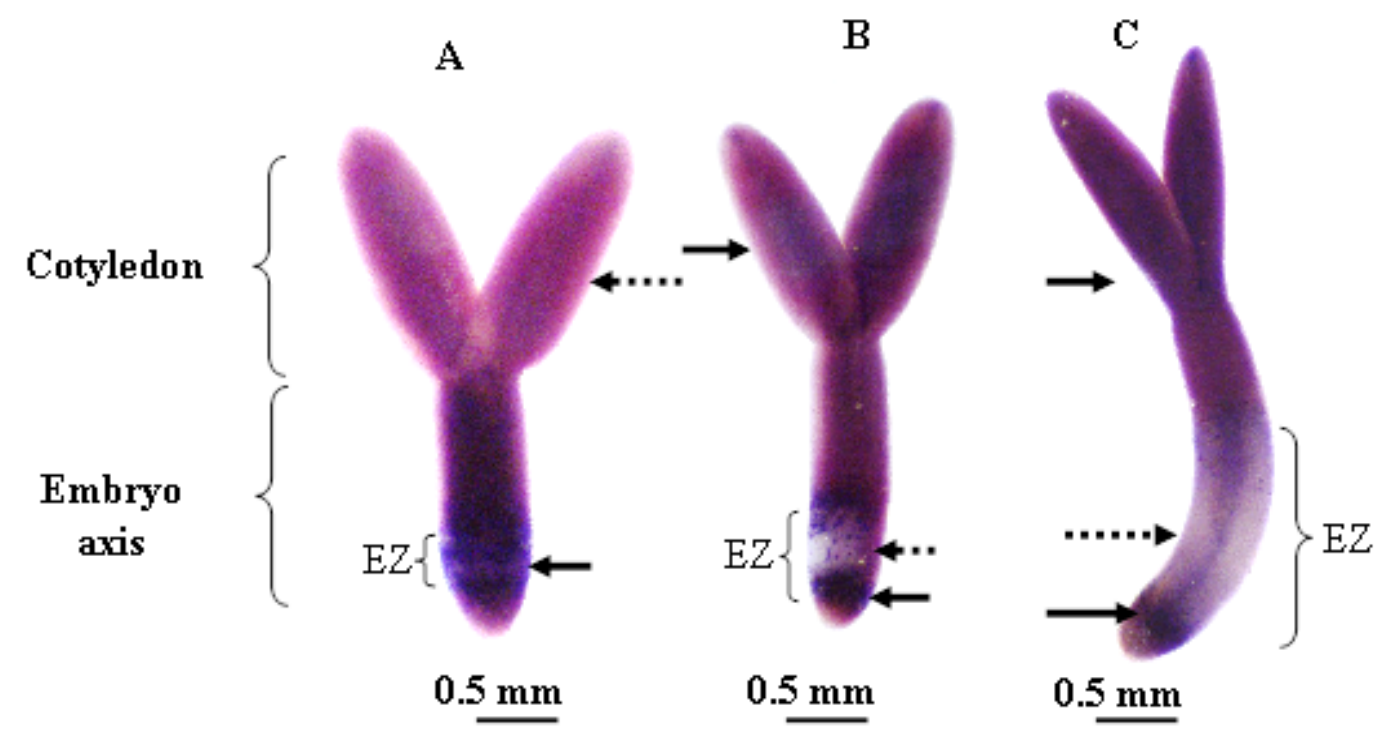

Fig. 4. Histochemical localization of the NBT reduction in embryos isolated from (A) salt imbibed seeds, $\left(\mathrm{B}^{-} \mathrm{H}_{2} \mathrm{O}^{-} \mathrm{im}^{-}\right.$ bibed seeds, and (C) seeds germinating in distilled water. The continuous arrows indicate high production of the superoxide anion radical $\left(\mathrm{O}_{2}^{-}\right)$and the discontinuous arrows indicate low production of the superoxide anion radical $\left(\mathrm{O}_{2}^{-}\right)$. Ez: Elongation zone

and exhibits a morphological dormancy. Following the imbibition of $C$. maritimum $\mathrm{L}$. seeds in distilled water, the embryo successfully grew, reaching $2 \mathrm{~mm}$ length at 6 $\mathrm{d}$, which is about the half of seed length. The same behaviour has been reported in carrot seeds (Homrichhausen et al., 2003). However, seed imbibition in $200 \mathrm{mM} \mathrm{NaCl}$ delayed the embryo growth, leading to the conclusion that salinity may inhibit the germination of $C$. maritimum $\mathrm{L}$. by extending the period required by the embryo to reach the critical level of growth, so that germination can take place. This finding is of high significance for halophytes, for which any delay of this process could adversely impact their establishment capacity under salt conditions (Easton and Kleindorfer, 2008). In addition, when the time of imbibition in $\mathrm{NaCl}$ solution was prolonged, $C$. maritimum L. seeds accumulated high concentrations of ions (data not shown), which may have also impaired key biochemical and physiological processes, hence delaying the physio- 
102

logical processes of germination and inhibiting the radicle emergence.

The embryo isolated from a salt-imbibed seed showed a reduction of the respiratory activity in the cotyledon area as compared to the cotyledons of the embryos isolated from water-imbibed seeds. In the germinating embryos, the activity remained high, but the elongation zone in embryo axis was characterised by a lower respiratory activity. Concomitantly, NBT staining revealed that independent of salt treatment, the embryo had high $\mathrm{O}_{2}{ }^{-2}$ production. As for respiratory activity, the salt reduced the $\mathrm{O}_{2}{ }^{--}$production in the cotyledon area. It is well known that in imbibed seeds, the reactivation of respiratory metabolism may be concomitant with high levels of ROS production (Garnczarska and Wojtyla, 2008). Thus, the reduction of the respiratory activity may have resulted in a decrease in $\mathrm{O}_{2}{ }^{--}$production in the cotyledon of $C$. maritimum $\mathrm{L}$. embryos. On the other hand, in the embryo axis of the embryos isolated from $\mathrm{H}_{2} \mathrm{O}$-imbibed seeds, we found low $\mathrm{O}_{2}$ - production in the elongation zone, especially in germinating embryo. Yet, in the axis of embryo isolated from seeds imbibed in salt solution, the elongation zone is significantly reduced. Similarly, in Allium cepa (CordobaPedregosa et al., 2005) and Pisum sativum (Kranner et al., 2010) radicle, the NBT was not reduced by the cells of the elongation zone. As assumed by Schopfer et al. (2001), it is likely that the $\mathrm{O}_{2}^{--}$produced in the elongation zone was converted by peroxidase to hydroxyl ions ${ }^{\circ} \mathrm{OH}$. It is well known that the latter is implicated in the cell elongation of the embryo axis during germination (Garnczarska and Wojtyla, 2008; Müller et al., 2009). The visualisation of the elongation zone shows that the $\mathrm{NaCl}$ - salinity reduced the elongation zone in embryo axis. This confirms the fact that the salinity inhibits the embryo growth by inhibiting the cell elongation and/or the cell division process.

In conclusion, in $C$. maritimum $\mathrm{L}$. seeds imbibed in distilled water (optimal medium for the germination), the embryo requires $6 \mathrm{~d}$ to grow before germination can start. Yet, this process appeared to be salt-sensitive. $\mathrm{NaCl}$-salinity reduced the embryo growth, the respiratory metabolism, and $\mathrm{O}_{2}{ }^{--}$production in the cotyledon.

\section{References}

Ashraf MY, Afaf R, Qureshi MS, Naqvi MH (2002). Salinity induced changes in $\alpha$-amylase and protease activities and associated metabolism in cotton varieties during germination and early seedling growth stages. Acta Physiol Plant 24:3744.

Atia A, Ben Hamed K, Debez A, Abdelly C (2006). Salt and seawater effects on the germination of Crithmum maritimum L., p. 29-33. In: Özturk M, Waisel Y, Khan MA, Görk G, (Eds.) Biosaline agriculture and salinity tolerance in plants. Birkhauser Verlag, Switzerland.

Atia A, Debez A, Zouhaier B, Abdelly C, Smaoui A (2010a). Localization and composition of seed oils of Crithmum maritimum L. (Apiaceae). Afr J Biotechnol 39:6482-6485.

Atia A, Debez A, Abdelly C, Smaoui A (2010b). Relationship between ion content in seed and spongy coat of the medicinal halophyte Crithmum maritimum L. and germination capacity. Not Sci Biol 2(2):72-74.

Bailly C (2004). Active oxygen species and antioxidants in seed biology. Seed Sc Res 14:93-107.

Bailly C, El-Maarouf-Bouteau H, Corbineau F (2008). From intracellular signaling networks to cell death: the dual role of reactive oxygen species in seed physiology. CR Biol 331:806-814.

Baskin JM, Baskin CC (2004). A classification system for seed dormancy. Seed Sc Res 14:1-16.

Bellani L, Guarnieri M, Scialabba A (2002). Differences in the activity and distribution of peroxidase from three different portions of germinating Brassica oleracea seeds. Physiol Plantarum 114:102-108.

Bewly JD (1997). Seed germination and dormancy. Plant Cell 9:1055-1066.

Block MD, Brouwer DD (2002). A simple and robust in vitro assay to quantify the vigour of oilseed rape lines and hybrids. Plant Physiol Biochem 40:845-852.

Côme D (1982). Germination p. 129-225. In: Mazliak P (Ed.). Croissance et développement. Physiologie végétale II: Paris, Hermann.

Cordoba-Pedregosa MDC, Villalba JM, Cordoba F, GonzalèzReyes A (2005). Changes in intracellular and appoplastic peroxidase activity, ascorbate redox status, and root elongation induced by enhanced ascorbate content in Allium cepa L. J Exp Bot 56:685-694.

Debez, A, Ben Hamed K, Grignon C, Abdelly C (2004). Effect on germination, growth and seed production of the halophytes Cakile maritima. Plant Soil 262:179-189.

Easton LC, Kleindorfer S (2008). Effects of salinity levels and seed mass on germination in Australian species of Frankenia L. (Frankeniaceae). Env Exp Bot 65:345-352.

Fry SC (1998). Oxidative scission of plant cell wall polysaccharides by ascorbate induced hydroxyl radicals. Biochem J 332:507-515.

Garnczarska M, Wojtyla $Ł$ (2008). Differential response of antioxidative enzymes in embryonic axes and cotyledons of germinating lupine seeds. Acta Physiol Plant 30:427-432

Homrichhausen TM, Hewitt JR, Nonogaki H (2003). Endo$\beta$-mannanase activity is associated with the completion of embryogenesis in imbibed carrot (Daucus carota) seeds. Seed Sc Res 13:219-227.

Joshi AJ, Mali BS, Hinglajia H (2005). Salt tolerance at germination and early growth of two forage grasses growing in marshy habitats. Env Exp Bot 54:267-274.

Kranner I, Roach T, Beckett RP, Whitaker C, Farida VM (2010). Extra cellular production of reactive oxygen species during seed germination and early seedling growth in Pisum sativum. J Plant Physiol 167:805-811. 
Meot-Duros L, Le Floch G, Magné C (2008). Radical scavenging, antioxidant and antimicrobial activities of halophytic species. J Ethno 116:258-262.

Meot-duros L, Magné C (2008). Effect of salinity and chemical factors on seed germination in the halophyte Crithmum maritimum L. Plant Soil 313:83-87.

Meot-duros L, Magné C (2009). Antioxidant activity and phenol content of Crithmum maritimum L. leaves. Plant Physiol Biochem 47:37-41.

Morohashi Y (2002). Peroxidase activity develops in the micropylar endosperm of tomato seeds prior to radicle protrusion. J Exp Bot 53:1643-1650.

Müller K, Linkies A, Vreeburg RAM, Fry SC, Krieger-Liszkay A, Leubner- Metzger G (2009). In Vivo cell wall loosening by hydroxyl radicals during cress seed germination and elongation growth. Plant Physiol 150:1855-1865.

Nikolaeva MG (1977). Factors controlling the seed dormancy pattern p. 51-74. In: Kahn AA (Ed). The physiology and biochemistry of seed dormancy and germination. Amsterdam: North-Holland.

Palmiano EP, Juliano BO (1973). Changes in the activity of some hydrolases, peroxidase, and catalase in the rice seed during germination. Plant Physiol 52:274-277.

Passardi F, Cosio C, Penel C, Dunand C (2005). Peroxidases have more functions than a swiss army knife. Plant Cell Report 24:255-265.
Schopfer P, Plachy C, Frahry G (2001). Release of reactive oxygen intermediates (superoxide radicals, hydrogen peroxide, and hydroxyl radicals) and peroxidase in germinating radish seeds controlled by light, gibberellin, and abscisic acid. Plant Physiol 125:1591-1602.

Sebei K, Debez A, Herchi W, Boukhchina S, Kallel H (2007). Germination kinetics and seed reserve mobilization in two flax (Linum usitatissimum L.) cultivars under moderate salt stress. J Plant Biol 50:447-454.

Sosa L, Llanes A, Reinoso H, Reginato M, Luna V (2005). Osmotic and specific ions effect on the germination of Prospis srtombulifera. Ann Bot 96:261-267.

Tobe K, Li X, Omasa K (2004). Effects of five different salts on seed germination and seedling growth of Haloxylon ammodendron (Chenopodiaceae). Seed Sc Res 4:345-353.

Voigt EL, Almeida TD, Chagas RM, Ponte LFA, Viégas RA, Silveira JAG (2009). Source-sink regulation of cotyledonary reserve mobilization during cashew (Anacardium occidentale) seedling establishment under $\mathrm{NaCl}$ salinity. J Plant Physiol 169:80-89.

Wojtyla Ł, Garnczarska M, Zalewski T, Bednarski W, Ratajczak L, Jurga $S$ (2006). A comparative study of water distribution, free radical production and activation of antioxidative metabolism in germinating pea seeds. J Plant Physiol 163:1207-1220. 